\title{
ÉVALUATION DE LA RESTAURATION DES RIVIĖRES CHENALISÉES POUR LE FLOTTAGE DU BOIS : ÉTUDE DU CAS DE LA RIVIERE KUTINJOKI, FINLANDE DU NORD.
}

\author{
A. HUUSKO (1) et T. YRJÄNÄ (2)
}

(1) Finnish Game and Fisheries Research Institute, Kainuu Fisheries Research and Aquaculture, FIN-88300 Paltamo, Finland.

(2) North Ostro-Bothnia Regional Environment Center, P.O. Box 124, FIN-90101 Oulu, Finland.

RÉSUMÉ (traduit par les éditeurs)

Au cours de la dernière décennie, plusieurs projets de restauration de rivières à grande échelle ont été initiés en Finlande, afin de réhabiliter la structure originale de l'habitat dans des rivières chenalisées pour le flottage du bois dans les années 19501960. L'objectif principal de la restauration est d'augmenter la diversité des berges et d'améliorer l'habitat des poissons en réarrangeant le substrat sur le fond de la rivière. Les digues de blocs utilisées sur la rivière Kutinjoki ont augmenté la diversité et la variabilité des profondeurs, des vitesses et des classes de substrats dominants disponibles, et ont augmenté la complexité spatiale des rapides. Sur les sites étudiés, les successions radiers-mouilles étaient clairement visibles après restauration et contrastaient avec les écoulements plus ou moins homogènes d'avant restauration. L'opération de restauration semble favoriser les truites de un an $(1+)$ et plus. Si l'on souhaite planifier et évaluer ce type d'amélioration de l'habitat piscicole, il est fortement conseillé d'utiliser une modélisation des conditions physiques et hydrologiques à une échelle pertinente pour les poissons et d'y inclure une analyse des préférences d'habitat des poissons.

\section{EVALUATING HABITAT RESTORATION OF RIVERS CHANNELIZED FOR LOG TRANSPORT : A CASE STUDY OF THE RIVER KUTINJOKI, NORTHERN FINLAND.}

\section{SUMMARY}

During the last decade, several extensive river restoration projects have been started in Finland aimed at restoring the original habitat structure in rivers channelized for log transport in the 1950's-1960's. The main goal of the restoration is to increase the diversity of the riverine environment and to enhance fish habitats by rearranging the substrate in the river bottom. Boulder dams employed in the river Kutinjoki increased the diversity and patchiness of available depths, velocities and dominant substrate sizeclasses making the rapids spatially more complex. The successive riffle - pool - structure at the study sites was clearly visible after the restoration, in contrast to the more or less homogenous pre-restoration flow pattern. The restoration procedure seems to favour $1+$ or older trout. For the planning and evaluation of fish habitat enhancement of this kind, it is highly advisable to employ the modelling of the hydro-physical conditions at the scale relevant to the fish and to include in the analysis the fish habitat preferences. 


\section{INTRODUCTION}

Until 1960s, log floating was a significant part of the forestry in Finland. The channels suitable for floating included $40000 \mathrm{~km}$ of the Finnish water courses (LAMMASSAARI, 1990). The channels were altered to allow the floating, which meant making the natural stream bed more homogenous by modifying the cross-section of the channels, streightening meanders and using embankments to isolate the shallow bays from the main channel (LAMMASSAARI, 1990 ; YRJÄNÄ, 1995). These measures simplified river habitats with the reduction in diversity of water velocity, depth and substrate particle sizes. All this led to changes in fish communities, especially the salmonids, which decreased significantly.

During the last decade several extensive projects have been started to restore the original habitat structure of channelized rivers. By 1991, some 90 restoration projects have been completed, covering an area of 500 hectares of rapids (YRJÄNÄ \& HUUSKO, 1992). The main goal of the restoration has been to increase the diversity of the riverine environment and to enhance fish habitats. The restoration is usually carried out by rearranging the substrate in the river bottom, most commonly by employing channel enlargements, boulder dams, riffles and deflectors made of boulders, placement of individual boulders, excavations, and spawning grounds made of transfered and sieved material (details in YRJÄNÄ, 1995).

So far, the evaluation of the effects of restoration on lotic environment have included water quality monitoring (YRJÄNÄ, 1995), short and long term effects on benthic fauna (TIKKANEN et al., 1994), monitoring fish densities (JUTILA et al., 1994) and an evaluation of artificial spawning grounds for salmonids (YRJÄNÄ, 1995). This paper documents, by means of a case study, the changes in physical habitat characteristics in certain rapids in order to show the improvement of habitat diversity gained by the restoration.

\section{A CASE STUDY}

\subsection{Study area}

The River Kutinjoki (26 km in length, drainage area $120 \mathrm{~km}^{2}, \mathrm{E} 28^{\circ} 20^{\prime}, \mathrm{N} 65^{\circ} 40^{\prime}$ ), a third order river in Northern Finland, is a tributary of the River Kostonjoki, one of the main tributaries of the River lijoki, a river running to the Baltic Sea. The gradient of the River Kutinjoki is $0.3 \%$, the annual mean flow being $1.4 \mathrm{~m}^{3} / \mathrm{s}$, the mean low summer flow $0.55 \mathrm{~m}^{3} / \mathrm{s}$ and the mean high flow (in spring) $17.4 \mathrm{~m}^{3} / \mathrm{s}$. The river runs through peatlands and coniferous forests with some deciduous trees and bushes along the shores. In general, the canopy is open. In the 1950's, all the salmonid reproduction and nursery areas (covering the total length of $6.6 \mathrm{~km}$ ) was dredged for floating

\subsection{Material and methods}

Three study sites was selected from the dredged river section. In it's pre-restoration state, each site was approximately $100 \mathrm{~m}$ long and $9 \mathrm{~m}$ wide (Table I). The main method employed in the restoration of the study sites was the construction of boulder dams (see WESCHE, 1985 ; YRJÄNÄ, 1995) for the rehabilitation of pool-riffle -patterns. Hydrophysical habitat characteristics, including water depth (in centimeters), mean water-column velocity (in centimeters per second at 0.4 times depth from the bed) and substrate (for classification see MALAVOI \& SOUCHON, 1989), were measured at 10-30 points along each of 10-12 transects at three study sites both before and after the restoration during the low flows (about 0.8-0.9 $\mathrm{m}^{3} \mathrm{~s}^{-1}$ ) in August and September 1993. The transects established within each site were selected to represent longitudinal segments having similar hydraulic and morphological conditions following guidelines of BOVEE (1982) and MALAVOI \& SOUCHON (1989). Froude number and Reynolds number were calculated from the measured variables by using the methods in DAVIS \& BARMUTA (1989).

In order to have a fish preference perspective for the restoration we compared the measured data to the habitat preference data of brown trout (Salmo trutta L.). The preference data of three size groups (young-of-year (5-10 cm long), $1+(10-15 \mathrm{~cm}$ long) and older (over $15 \mathrm{~cm}$ long)) were based on the material from the nearby River Kuusinkijoki (MÄKI-PETÄYS et al., 1994) and were calculated and standardized by the method 
presented in BALTZ et al., (1991). The preference indexes for depth, velocity and substrate were given for each measurement point. Median, mean, standard deviation and cofficient of variation of these point preference indexes were compared before and after restoration.

We used the Kruskal-Wallis one-way analysis of variance and the KolmigorovSmirnov test for continuous variables and the likelyhood ratio chi-square test (G-test) for discrete ones to determine if differences occurred in the frequency distributions between variables measured before and after restoration. The relative change in the frequency distributions was described by Jakob's index : $D=(r-p){ }^{*}((r-p) \text { * } 2 r p)^{-1}$ where $r=$ proportion of resource before restoration and $p=$ proportion of resource after restoration.

Tableau I : Moyenne et valeurs extrêmes des principales caractéristiques de l'habitat sur les sites d'étude à faible débit estival $\left(0.8-0.9 \mathrm{~m}^{3} \mathrm{~s}^{-1}\right)$ avant et après la restauration.

Table I : Mean and range of main habitat characreristics at the study sites before and after restoration at low summer flow $\left(0.8-0.9 \mathrm{~m}^{3} \mathrm{~s}^{-1}\right)$.

\begin{tabular}{cllllll}
\hline & $\begin{array}{l}\text { Before } \\
\text { Site 1 }\end{array}$ & Site 2 & Site 3 & $\begin{array}{l}\text { After } \\
\text { Site 1 }\end{array}$ & Site 2 & Site 3 \\
\hline Mean width m & 8.5 & 8.8 & 9.5 & 10.5 & 11.2 & 14.5 \\
$\quad$ Range & $7.6-9.9$ & $7.3-9.9$ & $8.3-10.2$ & $9.2-11.9$ & $9.6-12.49 .2-19.5$ \\
Mean depth cm & 24 & 32 & 32 & 27 & 29 & 30 \\
$\quad$ Range & $1-47$ & $7-94$ & $2-75$ & $3-65$ & $0-100$ & $0-150$ \\
Mean velocity cms ${ }^{-1}$ & 29 & 41 & 36 & 27 & 25 & 27 \\
$\quad$ Range & $0-121$ & $0-126$ & $0-130$ & $0-123$ & $0-129$ & $0-110$ \\
Mean substrate size-class & 5.9 & 6.4 & 6.7 & 6.2 & 6.9 & 5.7 \\
$\quad$ Range & $2-8$ & $3-8$ & $2-8$ & $0-9$ & $0-9$ & $0-9$ \\
Mean Froude number & 0.19 & 0.24 & 0.20 & 0.41 & 0.17 & 0.21 \\
$\quad$ Range & $0-0.81$ & $0-1.03$ & $0-0.89$ & $0-1.42$ & $0-0.97$ & $0-2.05$ \\
Mean Reynolds number $\times 10^{4}$ & 7.2 & 13.6 & 12.7 & 7.1 & 8.4 & 7.5 \\
$\quad$ Range & $0-30.4$ & $0-61.9$ & $0-55.0$ & $0-34.0$ & $0-53.0$ & $0-37.8$ \\
\hline
\end{tabular}

\section{RESULTS}

The restoration increased the river width from $22 \%$ (site 1) to $53 \%$ (site 3) (Table 1). As a result, the new river width approached the natural state of the river, which could be detected from the presence of old river banks in the riparian zone. Narrow ' $U$ ' or ' $V$ '-shaped cross-sections typical of the river in its pre-restoration state were changed into wider and more variable cross-sections.

The shape and location of the frequency distribution of the measured variables changed markedly in the restoration in all the other study sites (Fig. 1, for all variables KSmtest $p<0.005$, G-test $p<0.0001$ ) except at site 1 for velocity (KSm-test, for depth $p<0.0005$, but for velocity $p<0.1120$ ). The frequency distribution of substrate changed markedly in all the study sites (G-test, $p<0.0001$ ). The restoration increased the diversity and patchiness of available depths, velocities and dominant substrate size-classes making the rapids spatially more complex. Froude and Reynolds numbers indicated sub-critical or turbulent flow conditions (Table I). The successive riffle - pool -structure at the study sites was clearly seen after the restoration in contrast to the more or less homogenous pre-restoration flow pattern.

Before the restoration, there was a significant difference between the study sites in the velocity and the depth distributions ( $K-W$ anova, for both variables $p<0.01$ ) and also in 
the substrate size-class distribution (G-test, $p<0.0001$ ). After the restoration, only a small difference in the depth and the velocity distribution between them was noticeable $(\mathrm{K}-\mathrm{W}$ anova, for depth $p<0.6220$ and for velocity $p<0.2125$ ). Instead of that, there existed a significant difference in the substrate size class distribution (G-test, $p<0.0001$ ). The precentages of substrate size classes from 3 to 6 (gravel, cobbles, pebbles) of the study sites 1,2 and 3 were 67,58 and 23 before the restoration and 42,33 and 48 after the restoration. Therefore, the restoration seemed to make the hydro-physical conditions in all study sites quite similar.
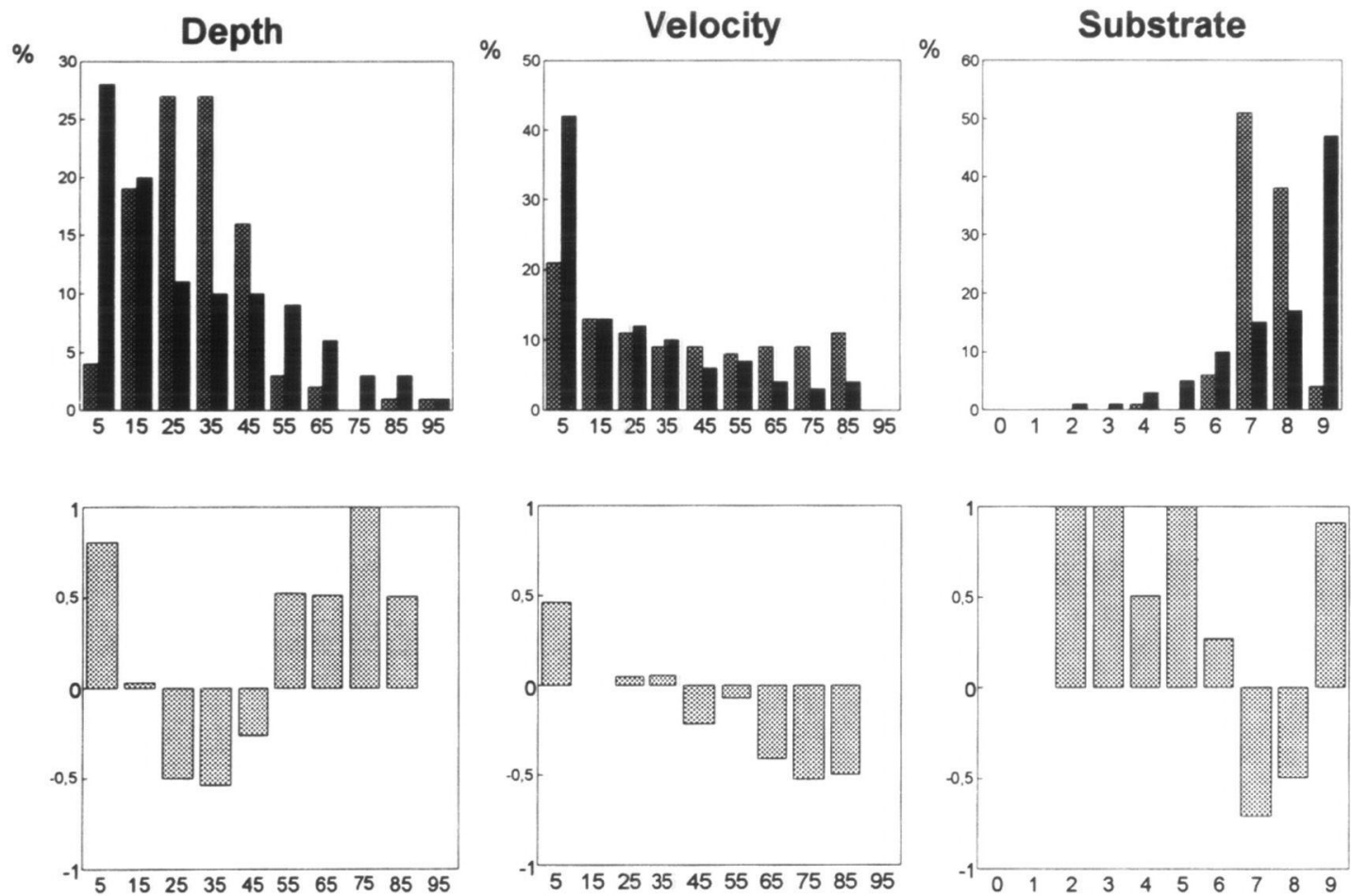

Figure 1 : Distribution de fréquences des classes de profondeur $(\mathrm{cm})$, de vitesse de courant $\left(\mathrm{cms}^{-1}\right)$ et de taille de substrat $(0=$ vase, $9=$ roche mère) avant (barres grises, $\mathrm{N}=200$ pour chaque variable) et après (barres noires, $\mathrm{N}=$ 226 pour chaque variable) restauration (en haut) avec les valeurs d'index de Jakob $(-1 \ldots 1)$ de l'évolution relative de la distribution de fréquence (en bas) sur le site d'étude 2.

Figure 1 : Frequency distributions of depth $(\mathrm{cm})$, velocity $\left(\mathrm{cms}^{-1}\right)$ and substrate size classes $(0=$ silt, $9=$ bedrock) before (grey bars, $N=200$ for each variable) and after (black bars, $\mathbf{N}=\mathbf{2 2 6}$ for each variable) restoration (above) with Jakob's index values $(-1 \ldots 1)$ of the relative change in the frequency distributions (below) at study site 2.

The assessment of the potential habitat suitability for brown trout indicated that substrate availability was limiting for $0+$ and $1+$ trout and depth availability was limiting for older trout both before and after restoration (at low summer flow, Table II). After the restoration, a small increase was discernible for $1+$ trout and a small decrease for $0+$ and $2+$ or older trout in substrate preference indexes. The same was true for depth for age- 0 fish. 
Tableau II : Index de préférence des différentes tailles de classe de truites communes (voir texte) pour la profondeur, la vitesse du courant et le substrat dominant, basé sur des mesures d'habitat ponctuelles ( $N=\mathbf{2 0 0}$ avant et $\mathbf{N}=226$ après restauration) sur le site d'étude 2 , donné à titre d'exemple. Pour chaque mesure ponctuelle, un index de préférence est attribué à chaque variable, basé sur les préférences d'habitat de la truite commune.

Table II : Brown trout preference indexes of different size-classes (see text) for depth, velocity and dominant substrate based on habitat measurement points ( $N=200$ before and $N=226$ after restoration) at the study site 2 as an example. For each measurement point, each variable was given a preference index based on the habitat preference data of the brown trout.

\begin{tabular}{lllllll}
\hline & $\begin{array}{l}\text { Depth } \\
\text { Before }\end{array}$ & After & $\begin{array}{l}\text { Velocity } \\
\text { Before }\end{array}$ & After & $\begin{array}{l}\text { Substrate } \\
\text { Before }\end{array}$ & After \\
\hline Size-class 1 $\mathbf{( 5 - 1 0 ~} \mathbf{~ c m ) ~}$ & & & & & & \\
Mean & 0.67 & 0.44 & 0.61 & 0.62 & 0.28 & 0.21 \\
Median & 0.77 & 0.58 & 0.60 & 0.60 & 0.22 & 0.19 \\
S. D. & 0.26 & 0.38 & 0.31 & 0.26 & 0.06 & 0.21 \\
C. V. & 39 & 87 & 50 & 41 & 23 & 95 \\
Size-class 2 (10 - 15 cm) & & & & & & \\
Mean & 0.33 & 0.41 & 0.52 & 0.53 & 0.29 & 0.33 \\
Median & 0.37 & 0.37 & 0.50 & 0.50 & 0.17 & 0.38 \\
S. D. & 0.20 & 0.28 & 0.22 & 0.21 & 0.14 & 0.26 \\
C. V. & 60 & 67 & 42 & 39 & 49 & 78 \\
Size-class 3 (over $\mathbf{1 5} \mathbf{~ c m ) ~}$ & 0.02 & 0.05 & 0.50 & 0.54 & 0.40 & 0.32 \\
Mean & 0.01 & 0.00 & 0.52 & 0.50 & 0.41 & 0.34 \\
Median & 0.03 & 0.16 & 0.27 & 0.21 & 0.17 & 0.29 \\
S. D. & 157 & 301 & 53 & 38 & 42 & 91 \\
C. V. & & & & & & \\
\hline
\end{tabular}

\section{DISCUSSION}

The temporal scale of our study is fairly narrow, both when it comes to the annual hydrological regime of the river and to the time lapsed after the restoration. It is obvious that annual events, such as floods (high flows), ice processes, sedimentation and others, will, through time, modify the habitat structures created during the restoration. The main habitat structures created in the restoration, however, will probably resist the normal force of natural disturbances, which means that most of the habitat diversity will be permanent.

An increased hydro-physical habitat complexity means that the potential availability of suitable microhabitats for fish and also for their food resources will be greater, improving the chances for successful enchancement of fish stocks. The long-term effects of the restoration beneficial for fisheries are linked not only with the stocking of the fish and management of the fisheries but also with the development of the biological complexity and its dynamics (mosses, higher vegetation, benthic animals) in the restored areas. The recolonization rate of macroinvertebrates to restored areas seems to be fast, since in most cases patches of the river bed were left intact, which serves the colonization sources (TIKKANEN et al., 1994). The reduction of moss cover in restored areas and its recovery rate, which is obviously slow, may emphasize the importance of substrate as a habitat component during the first two or three years immediately after the restoration. 
In the river Kutinjoki, post-restoration substrate availability seems to be limiting for the youngest age groups of trout. The restoration procedure employed seems to favour $1+$ or older trout, which is in agreement with the stocking and electrofishing results of JUTILA et al. (1994). Large boulder dams have also turned out to be the most effective single restoration measure to increase smolt production of trout in dredged rivers (NÄSLUND, 1987). In the river Kutinjoki the restoration material was taken from the embankments surrounding the original floating channel. In most cases, boulder dams were filled up with cobbles and pebbles, important components of preferred substrate in optimum microhabitats of young-of-year trout (HEGGENES et al., 1994). However, part of this small sized material should probably have been used for constructing shallow riffle habitat for small trout.

Evaluation of trout habitat on the basis of point suitabilities, which was carried out in this study, is at least partly unreliable, since the point indexes do not take into account the area they represent. Instead of comparing point suitabilities a better solution might be the PHABSIM-procedure (BOVEE, 1982) and its different applications (e.g. SOUCHON et al., 1990 ; JAGER et al., 1993 ; HEGGENES et al., 1994 ; PAYNE, 1994). Modelling hydrophysical conditions at a scale relevant to the fish (or its life-stage) combined with the fish (or its life-stage) habitat preferences can be a practical tool in river restoration. Among other things, the procedure offers one the possibility to evaluate the effects of the waterflow variation between the seasons to identify temporal bottlenecks in the available spatial habitat in order to focus the mitigating measures at the most limiting habitat components. PHABSIM also enables one to evaluate the restoration procedure while it is still in the planning phase (WEGNER, 1980).

\section{ACKNOWLEDGEMENTS}

Thanks are due to Olli van der MEER, Pasi HAUTAJÄRVI, Harri AHO and Esko KOIVURANTA for the help in the field work. Päivi TIMONEN is greatly acknowledged for valuable assistance in data analysis and Eeva-Kaisu KEMPPAINEN for checking the English language.

\section{REFERENCES}

BALTZ D.M., VONDRACEK B., BROWN L.R., MOYLE P.B., 1991. Seasonal changes in microhabitat selection of rainbow trout in a small stream. Trans. Am. Fish. Soc., 120, 166-176.

BOVEE K., 1982. A guide to stream habitat analysis using the instream flow incremental methodology. Instream flow information paper 12, U.S.D.I. Fish and Wildlife Service, Office of Biological Services. FWS/OBS-82/26.

DAVIS J.A., BARMUTA L.A., 1989. An ecologically useful classification of mean and nearbed flows in streams and rivers. Freshwat. Biol., 21, 271-282.

HEGGENES J., SALTVEIT S.J., VASKINN K.A., LINGAAS O., 1994. Predicting fish habitat use responses to changes in waterflow regime : modelling critical minimum flows for atlantic salmon, Salmo salar, and brown trout, Salmo trutta, in a heterogeneous stream. Proceedings of the first international symposium on habitat hydraulics (August 18-20,1994). The Norwegian Institute of technology. Trondheim, Norway.

JAGER H.I., De ANGELIS D.L., SALE M.J., van WINKLE W., SCHMOYER D.D., SABO M.J., ORTH D.J., LUKAS J.A., 1993. An individual-based model for smallmouth bass reproduction and young-of-year dynamics in streams. Rivers, 4 (2), 91-113.

JUTILA E., KARTTUNEN V., NIEMITALO V., 1994. Better one stone in the rapid than ten on the bank - Influence of various restoring methods on the parr densities of brown trout in the rapids of the tributaries flowing into the lijoki River. KalatutkimuksiaFiskeriundersökningar 87, 29 p. Finnish Game and Fisheries Research Institute, Helsinki, Finland. (in Finnish with English summary). 
LAMMASSAARI V., 1990. Floating and its effects on watercourses. Publications of the Water and Environment Administration. Series A 54, 235 p. Helsinki, Finland (in Finnish with English summary)

MÄKI-PETÄYS A., MUOTKA T., TIKKANEN P. HUUSKO A., KREIVI P., KUUSELA K., 1994. Size-class differences in microhabitat use by juvenile brown trout. Kalatutkimuksia-Fiskeriundersökningar 80, 38 p. Finnish Game and Fisheries Research Institute, Helsinki, Finland. (in Finnish with English summary).

MALAVOI J. R., SOUCHON Y., 1989. Méthodologie de description et quantification des variables morphodynamiques d'un cours d'eau à fond caillouteux : exemple d'une station sur la Fillière (Haute-Savoie). Revue de Géographie de Lyon, 64, 252-259.

NÄSLUND I., 1987. Effects of habitat improvement on the brown trout (Salmo trutta L.) population of a North Swedish river. Information från Sötvattenslaboratoriet, Drottningholm. 1987/3, 28 p. (in Swedish with English summary)

PAYNE T. R., 1994. RHABSIM : user-friendly computer model to calculate river hydraulics and aquatic habitat. Proceedings of the first international symposium on habitat hydraulics (August 18, 20,1994). The Norwegian Institute of technology. Trondheim, Norway.

SOUCHON Y., TROCHERIE F., FRAGNOUD E., LACOMBE C., 1990. Les modèles numériques des microhabitats des poissons : application et nouveaux développements. Revue des Sciences de l'Eau, 2 (4), 807-830.

TIKKANEN P., LAASONEN P., MUOTKA T., HUHTA A., KUUSELA K., 1994. Short-term recovery of benthos following disturbance from stream habitat rehabilitation. Hydrobiologia, 273, 121-130.

WEGNER D.L., 1980. Evaluation and simulation of aquatic habitat improvements. Thesis for Master of Science. Colorado State University, Fort Collins, Colorado, U.S.A. 155 p.

WESCHE T.A., 1985. Stream channel modifications and reclamation structures to enchance fish habitat. In GORE J.A., The restoration of streams and rivers, 103-164. Butterworth, Stoneham.

YRJÄNÄ T., 1995. Restoration of Running Waters within the lijoki River Area. In DeWAAL L., LARGE A.R.G. \& WADE M. (eds), Rehabilitation of Rivers, Wiley Publication, (accepted manuscript).

YRJÄNÄ T., HUUSKO A., 1992. Enhancement of fish habitats in Finnish rivers. Suomen kalastuslehti, 99 (6), 26-27. (in Finnish). 